\title{
FUTURAS E ATUAIS APLICAÇÕES DA REALIDADE MISTA PARA FINALIDADES DIDÁTICAS
}

\author{
Caterina Bomfim Brasil \\ Graduanda em Design PUC-Rio \\ catebrasil@hotmail.com \\ Cláudia Mont'Alvão \\ Professora Associada PPGDesign PUC-Rio \\ cmontalvao@puc-rio.br
}

Resumo: O termo de Realidade aumentada (AR, RA, ou realidade ampliada) surgiu em meados dos anos 90, quando o engenheiro Ivan Sutherland criou um sistema para auxiliar mecânicos de uma empresa de aviação. O sistema funcionava com um óculos especial. Já o conceito de Realidade virtual só chegou ao público em meados dos anos 50, quando o cineasta Morton Heilig construiu um console baseado em um sistema de filme 3D, que viria acompanhado de outros artifícios que poderiam levar o público a uma experiência mais imersiva ao assistir a um filme. Nos anos 60, foi desenvolvido o primeiro HMD (head mounted display), que incluía uma tela de vídeo e um sistema de rastreamento. A diferença entre as duas tecnologias consiste na forma como a pessoa se relaciona com os elementos criados virtualmente. A realidade aumentada traz uma proposta que insere elementos digitais ao meio real. Já a realidade virtual permite que o usuário imerja em um meio totalmente virtual. Quando o assunto é $A R$, vale ressaltar o uso de Mapeamento de projeção (projection mapping), uma tecnologia que segue os princípios da RA, na maioria das vezes é usada para modificar ou adicionar algum elemento virtual projetado em algo material. Para ter acesso a tecnologia, é necessário um software especializado, podendo este ser mapeado em duas ou três dimensões. A projeção pode ser desde paisagens complexas e interativas (com o apoio de sensores) até um simples jogo de cores. Para usufruir da tecnologia da RA são necessárias algumas ferramentas. O sistema utilizado deve se basear em um software capaz de capturar imagens do campo real, e inserir os elementos virtuais por meio de uma lente. Essas lentes podem ser projetores conectados a uma câmera 3D e HMDs, que são capacetes integrados com duas telas diferentes que reproduzem duas imagens, uma para cada olho. Com efeito da estereoscopia, o cérebro interpreta que as duas imagens são na realidade, uma só. Estamos vivendo em uma era digital. Devido a essa aproximação crescente com a tecnologia, e sua inserção no dia-a-dia, estamos cada vez mais abertos e confortáveis para aplicar a tecnologia em qualquer atividade. O acesso da RA está cada vez mais fácil, e já pode ser acessado diretamente pelo smartphone (com ou sem a utilização do Google Cardborad). Grandes empresas e redes sociais 
estão adaptando suas plataformas para inserir a tecnologia em seu conteúdo digital. A RA pode ser utilizada como ferramenta de apoio para algumas atividades, e já está sendo explorada nas áreas da engenharia, arquitetura, medicina, geografia, entre outras. Muitos ainda relacionam o termo de Realidade Mista diretamente aos jogos. Porém, as possibilidades de aplicação da RA podem ser muito mais bem aproveitadas no âmbito acadêmico ou como ferramenta para atividades do dia-a-dia, considerando o poder didático e interativo da ferramenta.

Palavras-chave: Realidade aumentada, realidade virtual, vida digital 